\title{
Pengaruh Penggunaan Alat Pelindung Diri Terhadap Terjadinya Gejala Infeksi Saluran Pernafasan Akut (ISPA) pada Pegawai Dinas Perhubungan Kota Jakarta Timur
}

\author{
"Dwi Wahyuni ${ }^{1)}$, Yuyun Kurniawati ${ }^{2)}$
}

Program Studi S1 Kesehatan Masyarakat, Fakultas Kesehatan, Universitas Mohammad Husni Thamrin

Corresponden author: dwiwahyuni1102@gmail.com

Received : 17 Maret $2021 \quad$ Accepted : 30 Maret 2021

Published: 30 Maret 2021

DOI: https://doi.org/10.37012/jik.v13i1.414

\begin{abstract}
ABSTRAK
Infeksi Saluran Pernapasan Akut (ISPA) merupakan penyakit saluran pernapasan akut bagian bawah yang dapat berlangsung selama 14 hari. Kasus ISPA dapat menyerang kelompok rentan seperti pegawai LLAJ yang terpapar polutan udara luar, tentunya penggunaan APD sangat diperlukan. Penelitian ini bertujuan untuk menganalisis pengaruh penggunaan APD terhadap gejala ISPA pada pegawai LLAJ di Kota Jakarta Timur. Desain menggunakan observasional analitik dengan pendekatan cross sectional study. Teknik pengambilan sampel secara Non-Probability Sampling dengan metode Purposive Sampling. Kriteria inklusi dari sampel adalah pegawai LLAJ yang kesehariannya bertugas di jalan raya, dengan total sampel diperoleh berjumlah 134 responden dari 9 kecamatan di wilayah Jakarta Timur. Hasil univariat pegawai laki-laki sebanyak 84\%, 100\% Responden menggunakan APD masker (79\% menggunakan masker kain, 10\% menggunakan masker bedah, $2 \%$ menggunakan masker N95\% dan 9\% masker lainnya), lama pajanan < 8 jam/hari sebanyak 99\%, masa kerja > 5tahun sebanyak 4,5\%, responden yang mengalami gejala-gejala ISPA selama 14 hari sampai 1 bulan terakhir $2,24 \%$ yang mengalami batuk saat bekerja, 1,5\% mengalami tenggorokan terasa sakit, 5,22\% mengalami pilek/hidung tersumbat/berair dan $0,7 \%$ mengalami batuk dengan pernafasan cepat (>50/mnt). Perlunya penggunaan APD masker, rotasi kerja dan pemeriksaan kesehatan di awal pekerjaan dan dilakukan secara berkala dalam pengendalian ISPA.
\end{abstract}

Kata Kunci: APD, gejala ISPA, pegawai LLAJ.

\section{ABSTRACT}

ARTI is a disease of the acute respiratory tract and lower part of the tract that can last for 14 days. The study aims to analyzed the effect of the use of PPE toward ARTI symptoms on TAT employees at East Jakarta. The design uses the cross-sectional study. The sampling technique uses the purposive sampling method. The inclusive criteria of the sample are TAT employees who work on the highway on a daily basis, and the total sample are 134 respondents from 9 sub-districts. The result shows that $84 \%$ respondents are male employees, $100 \%$ respondents wear PPE (79\% wear cloth-based mask, $10 \%$ wear medical mask, $2 \%$ wear $N-95$ mask, and 9\% wear other kind of mask), 99\% respondent get $<8$ hour per day exposure, There are 4,5\% respondents who had ARTI symptoms for 14 days to the last month, 2,24\% that experienced cough at work, 1,5\% that got sore throat, 5,22\% that got nasal runny nose / nasal congestion and $0,7 \%$ who experienced cough with rapid breathing (>50/minute). It is important to wear PPE mask, to provide work rotation, to conduct medical check-up at the beginning of employment and also the regular check-up in order to prevent ARTI.

Keywords: PPE, ARTI Symptoms, Traffic and Transportation Employees. 


\section{PENDAHULUAN}

International Labour Organization (ILO) pada tahun 2013 melaporkan bahwa diperkirakan sebesar 2,02 juta orang meninggal dari berbagai penyakit yang berhubungan dengan pekerjaan yang terkena paparan gas, uap dan debu (Iriyana, 2014). Hasil Riskesdas pada tahun 2013 melaporkan insiden dan pervalensi penyakit saluran pernapasan akut di Indonesia tahun 2013 adalah sebesar 1,8\% dan 4,5\% (Riskesdas, 2013). Adapun penyakit ini bisa terjadi karena adanya pembakaran dari asap rokok, pembakaran gas buang dari transportasi atau kendaraan bermotor, indrustri dan kebakaran hutan serta lain-lain (Romdhoni \& Riyanto, 2015).

Infeksi Saluran Pernapasan Akut (ISPA) adalah penyakit saluran pernapasan akut yang meliputi saluran pernapasan bagian atas seperti rhinitis, faringitis, dan otitis serta saluran pernapasan bagian bawah seperti laryngitis, bronkhitis, bronkhiolitis dan pneumonia, yang dapat berlangsung selama 14 hari. Batas waktu 14 hari diambil untuk menentukan batas akut dari penyakit tersebut. Saluran pernapasan terdiri dari organ mulai dari hidung sampai alveoli beserta sinus, ruang telinga tengah dan pleura (Depkes RI, 2005).

Lingkungan memberikan sumbangan dampak dari pencemaran udara terhadap kesehatan seperti gangguan saluran pernapasan. Pencemaran udara memipunyai hubungan yang erat dengan kejadian penyakit pernapasan (Putra \& Sulistyorini, 2016).

Jalan raya merupakan lokasi yang banyak menimbulkan bahaya bagi penggunanya. Bahaya/Hazard dalam istilah Keselamatan dan Kesehatan Kerja (K3) adalah segala sesuatu termasuk diantaranya situasi yang berpotensi menimbulkan kecelakaan atau cedera pada manusia, kerusakan atau gangguan lainnya. Salah satu bahaya yang ditimbulkan bagi pengguna jalan raya adalah gejala ISPA (Infeksi Saluran Pernapasan Akut).

Pegawai yang bekerja pada Bidang Lalu Lintas dan Angkutan Jalan (LLAJ) merupakan salah satu profesi yang rentan terhadap terjadinya gangguan fungsi paru akibat seringnya terpapar terhadap polusi dan urusan lalu lintas di jalan raya. Sumber polutan berasal dari beberapa kegiatan seperti sektor transportasi sebesar 25\%, 15\% dari kegiatan industri, $20 \%$ oleh pembakaran biomasa, $22 \%$ dari aktivitas manusia dan 18\% dari debu alami dan garam laut. Sektor transportasi yang menjadi penyumbang utama dalam pencemaran udara, yaitu $44 \%$ TSP (Total Suspanded Particulate), 89\% Hidrokarbon dan 73\% NOx. Seiring dengan berkembangnya suatu kota seperti pembangunan fisik mengakibatkan kota dan pusat industri juga turut serta dalam penurunan kualitas udara. 
Besarnya polutan di jalan raya akan sangat berisiko untuk terjadinya gangguan pernafasan pada pekerja di jalan raya. Penggunaan APD merupakan faktor penting yang harus diperhatikan pada saat melaksanakan tugas. Selain itu faktor lain yang mungkin mempengaruhi adalah karakteristik yang terdapat pada individu pekerja seperti usia, jenis kelamin, kebiasaan merokok, lama kerja, status gizi,dan lama terpajan. Kajian terhadap faktor yang berhubungan ini akan menjadi solusi yang akan dicapai baik dalam usaha promotif, preventif, maupun kuratif dan rehabilitasi terhadap penyakit atau keluhan kesehatan yang yang diakibatkan oleh faktor pekerjaan dan lingkungan kerja.

Bahaya yang sudah diidentifikasi memerlukan beberapa langkah pengendalian ke titik yang aman. Penggunaan APD merupakan pengendalian ditingkat akhir. Salah satu cara yang dapat digunakan untuk mengendalikan bahaya yang terdapat di jalan raya adalah penggunaan APD. Jenis APD yang banyak digunakan adalah masker. Masker dapat digunakan sebagai salah satu cara menangkal virus atau zat-zat berbahaya lain yang masuk ke dalam tubuh. Jika tidak menggunakan APD seperti masker, maka virus atau zat-zat berbahaya lain akan lebih cepat masuk ke dalam tubuh dan menimbulkan bahaya atau penyakit.

Tujuan umum penelitian ini untuk menganalisis pengaruh penggunaan APD terhadap gejala ISPA pada pegawai LLAJ di Kota Jakarta Timur. Sedangkan tujuan khusus untuk mengetahui distribusi frekuensi gejala ISPA, penggunaan APD, distribusi frekuensi usia, jenis kelamin, status gizi, masa kerja dan perilaku merokok, dan lama pajanan di jalan raya serta untuk menganalisis pengaruh penggunaan APD terhadap gejala ISPA pada pegawai LLAJ, setelah dikontrol oleh variabel usia, jenis kelamin, status gizi, masa kerja, perilaku merokok, dan lama pajanan di jalan raya.

\section{METODE}

Penelitian ini dilakukan pada Pegawai Lalu Lintas dan Angkutan Jalan (LLAJ), Dinas Perhubungan Kota Jakarta Timur dengan desain penelitian survey observasional analitik dengan pendekatan kroseksional. Metode pengumpulan data menggunakan Teknik pengambilan sampel "Non-Probability Sampling dengan metode Purposive Sampling. Kriteria inklusi dari sampel adalah pegawai yang bekerja di Jalan raya, dan pengambilan data dilakukan pada saat pegawai sedang menjalankan tugasnya di jalan raya. Jumlah sampel diperoleh dari rumus sampel uji hipotesis beda 2 proporsi dan diperoleh sampel sejumlah 158 orang. Seluruh sampel terpilih akan diwawancara dengan menggunakan instrumen pertanyaan terstruktur (kuisioner) oleh enumerator atau peneliti langsung. Selain itu juga 
dilakukan pengukuran Tinggi badan dan Berat badan untuk mengukur status gizi.

\section{HASIL DAN PEMBAHASAN}

\section{Hasil}

Penelitian ini dilakukan pada 9 titik tempat Pegawai LLAJ Jakarta Timur bekerja. Berdasarkan hasil wawancara yang telah dikumpulkan yaitu sebanyak 134 responden yang terbagi dalam 9 kecamatan maka didapatkan hasil sebagai berikut:

Tabel 1.

Lokasi Pengambilan Data pada Pegawai LLAJ Jakarta Timur

\begin{tabular}{lcc}
\hline Lokasi Penelitian (Unit/Kecamatan) & $\begin{array}{c}\text { Frekuensi } \\
(\mathbf{n = 1 3 4 )}\end{array}$ & $\begin{array}{c}\text { Persentase } \\
(\mathbf{\%})\end{array}$ \\
\hline Kecamatan Pulo Gadung & 7 & 5,2 \\
Kecamatan Matraman & 3 & 2,2 \\
Kecamatan Jatinegara & 22 & 16,4 \\
Kecamatan Cakung & 22 & 16,4 \\
Kecamatan Kramat Jati & 15 & 11,2 \\
Kecamatan Makasar & 14 & 10,4 \\
Kecamatan Ciracas & 22 & 16,4 \\
Kecamatan Cipayung & 20 & 14,9 \\
Kecamatan Pasar Rebo & 9 & 6,7 \\
\hline
\end{tabular}

Pelaksanaan pengumpulan data dilakukan pada saat pandemic covid 19 sehingga wawancara dan pengukuran status gizi tidak dapat dilakukan secara langsung, Demikian juga tidak dapat secara langsung melihat atau mengobservasi kegiatan keseharian dari semua responden. Pengumpulan data kami lakukan dengan menggunakan googleform yang di share melalui ponsel responden.

Berdasarkan tabel 2 di bawah, bahwasanya pegawai di LLAJ lebih banyak berjenis kelamin laki-laki (84\%), Usia pegawai paling banyak antara 21-30 tahun (60,4\%), Masa kerja paling lama pengalaman kerjanya sekitar 3-4 tahun sebanyak 34,3\%, Pekerja dengan lama pajanan di lapangan atau terpapar polutan udara di jalanan dengan lama pajanan adalah 8 jam per hari sebanyak 74.63\%, walaupun dalam kesehariannya di lapangan selalu menggunakan masker, hanya saja jenis masker yang digunakan beragam, seperti masker kain (79\%), masker bedah (10\%), masker N95 (2\%). Perilaku merokok bagi pekerja LLAJ sebanyak 46\%, status gizi pegawai cenderung berstatus gizi normal sebanyak $93 \%$. 
Tabel 2.

Jenis Kelamin, Usia, Masa Kerja, Lama Pajanan, Perilaku Merokok, Status Gizi, Penggunaan APD Masker, dan Gejala ISPA pada Pegawai LLAJ Jakarta Timur

\begin{tabular}{|c|c|c|c|}
\hline No & Variabel & $\begin{array}{c}\text { Frekuensi } \\
(n=134)\end{array}$ & $\begin{array}{c}\text { Persentase } \\
(\%)\end{array}$ \\
\hline \multirow{3}{*}{1.} & Jenis kelamin & & \\
\hline & - Laki-laki & 113 & 84 \\
\hline & - Perempuan & 21 & 16 \\
\hline \multirow[t]{5}{*}{2.} & Usia & & \\
\hline & - usia 21-30 tahun & 81 & 60.4 \\
\hline & - usia 31-40 tahun & 37 & 27.6 \\
\hline & - usia 41-50 tahun & 13 & 9.7 \\
\hline & - usia diatas 50 tahun & 3 & 2.2 \\
\hline \multirow[t]{7}{*}{3.} & Masa Kerja & & \\
\hline & $-\leq 1$ tahun & 35 & 26.1 \\
\hline & $->1-2$ tahun & 8 & 6 \\
\hline & - >2-3 tahun & 12 & 9 \\
\hline & - >3-4 tahun & 46 & 34.3 \\
\hline & - >4-5 tahun & 27 & 20.1 \\
\hline & $->5$ tahun & 6 & 4.5 \\
\hline \multirow[t]{10}{*}{4.} & Lama Pajanan & & \\
\hline & -1 jam & 2 & 1.49 \\
\hline & $-2 \mathrm{jam}$ & 1 & 0.75 \\
\hline & -4 jam & 7 & 5.22 \\
\hline & $-5 \mathrm{jam}$ & 2 & 1.49 \\
\hline & $-6 \mathrm{jam}$ & 4 & 2.99 \\
\hline & $-7 \mathrm{jam}$ & 16 & 11.94 \\
\hline & -8 jam & 100 & 74.63 \\
\hline & -10 jam & 1 & 0.75 \\
\hline & -12 jam & 1 & 0.75 \\
\hline \multirow[t]{3}{*}{5.} & Perilaku Merokok & & \\
\hline & - Ya Merokok & 62 & 46 \\
\hline & - Tidak Merokok & 72 & 54 \\
\hline \multirow[t]{4}{*}{6.} & Status Gizi & & \\
\hline & - Gizi Normal & 124 & 93 \\
\hline & - Gizi Kurang & 2 & 1 \\
\hline & - Gizi Lebih & 8 & 6 \\
\hline \multirow[t]{2}{*}{7.} & Penggunaan Masker & & \\
\hline & - Ya menggunakan Masker & 134 & 100 \\
\hline \multirow[t]{5}{*}{8.} & Jenis Masker & & \\
\hline & - Masker Kain & 106 & 79 \\
\hline & - Masker Bedah & 13 & 10 \\
\hline & - Masker N95 & 3 & 2 \\
\hline & - Masker lainnya & 12 & 9 \\
\hline \multirow[t]{7}{*}{9.} & Gejala ISPA selama 14 hari s/d 1 bulan terakhir & & \\
\hline & - Mengalami Batuk-batuk saat bekerja & 3 & 2.24 \\
\hline & - Mengalami Tenggorokan Terasa Sakit & 2 & 1.5 \\
\hline & - Mengalami Pilek/hidung tersumbat/berair & 7 & 5.22 \\
\hline & $\begin{array}{l}\text { - Mengalami Sesak Napas yang disertai atau tanpa disertai } \\
\text { panas atau demam }\left(>37^{\circ} \mathrm{C}\right)\end{array}$ & 0 & 0 \\
\hline & - Mengalami Keluar cairan dari telinga tanpa rasa sakit & 0 & 0 \\
\hline & - Mengalami Batuk dengan pernafasan cepat (>50/mnt) & 1 & 0.7 \\
\hline
\end{tabular}


Gejala sakit mengarah ke ISPA cenderung kecil yaitu sebanyak 5,22\% mengalami pilek/hidung tersumbat/berair, yang mengalami batuk-batuk saat bekerja hanya $2,24 \%$ dan yang mengalami tenggorokan terasa sakit sebanyak 1,49\%. Pertanyaan-pertanyaan yang diajukan kepada responden dapat mengakibatkan bias karena ada pertanyaan yang harus diingat oleh responden selama 14 hari ataupun 1 bulan terakhir terutama kepada pertanyaan mengenai gejala penyakit.

Pada penelitian ini, untuk mengetahui gejala ISPA pada responden kami menggunakan kuesioner yang berisikan gejala-gejala ISPA. Analisis pengaruh penggunaan Alat Pelindung Diri (APD) terhadap terjadinya gejala Infeksi Saluran Pernafasan Akut (ISPA) tidak dapat kami lakukan karena jumlah kasus yang kecil dan semua responden menggunakan APD. Hal ini terjadi karena penelitian ini dilakukan pada saat kondisi Pandemic Covid 19 dan adanya pemberlakuan wajib $3 \mathrm{M}$ yaitu memakai masker, mencuci tangan dan menjaga jarak. Selain itu karena adanya keterbatsan ruang gerak atau Pembatasan Sosial Berskala Besar (PSBB) mengakibatkan paparan udara atau emisi udara dari mobilisasi kendaraan bermotor sangat rendah, maka penjaringan kasus ISPA yang dirasakan oleh responden pun menjadi rendah bahkan cenderung tidak merasakan gangguan pernafasan dibandingkan dengan paparan polutan sebelum terjadinya pandemic covid 19.

\section{Pembahasan}

ISPA (Infeksi Saluran Pernafasan Akut) merupakan Penyakit infeksi yang menyerang salah satu bagian dan atau lebih dari saluran napas, mulai dari hidung (saluran atas) hingga alveoli (saluran bawah) termasuk jaringan adneksanya, seperti sinus, rongga telinga tengah dan pleura yang berlangsung selama 14 hari yang disebabkan oleh agen infeksius yang ditularkan dari manusia kemanusia dengan gejala adalah demam, batuk, dan sering juga nyeri tenggorok, coryza (pilek), sesak napas, menggigil, atau kesulitan bernapas. Faktor penyebab ISPA menurut WHO adalah rhinovirus, respiratory syncytial virus, paraininfluenzaenza virus, severe acute respiratory syndrome-associated coronavirus (SARS-CoV), dan virus Influenza (https://www.who.int).

Cara pemeriksaan ISPA adalah Anamnesis yaitu demam suhu > $38 \mathrm{C}$, batuk dan sesak, ditanyakan pula riwayat bepergian dari negara timur tengah 14 hari sebelum onset. Sedangkan pemeriksaan fisik adalah sesuai dengan gambaran pneumonia, pemeriksaan radiologi dengan Foto toraks dapat ditemukan infiltrat, konsolidasi sampai gambaran ARDS. Pemeriksaan laboratorium ditentukan dari pemeriksaan PCR dari swab tenggorok dan sputum. (https://www.kemkes.go.id) 
Patogen yang paling sering menyebabkan ISPA adalah virus, atau infeksi gabungan virusbakteri. Ancaman ISPA akibat organisme baru yang dapat menimbulkan epidemi atau pandemi memerlukan tindakan pencegahan dan kesiapan khusus seperti kondisi lingkungan misalnya polutan udara, kepadatan anggota keluarga, kelembaban, kebersihan, kondisi musim dan temperatur/suhu, ketersediaan dan efektivitas pelayanan kesehatan dan langkah pencegahan infeksi untuk mencegah penyebaran misalnya; vaksin, akses terhadap fasilitas pelayanan kesehatan, kapasitas ruang isolasi, faktor pejamu seperti usia, kebiasaan merokok, kemampuan pejamu menularkan infeksi, status kekebalan, status gizi, infeksi sebelumnya atau infeksi serentak yang disebabkan oleh patogen lain, kondisi kesehatan umum. karakteristik patogen, seperti cara penularan, daya tular, faktor virulensi misalnya, gen penyandi toksin, dan jumlah atau dosis mikroba (ukuran inokulum). (https://www.who.int)

Usia merupakan salah satu faktor risiko ISPA. Penelitian yang dilakukan oleh Noer \& Martiana (2013) pada kelompok pekerja menyebutkan usia merupakan salah satu faktor yang mempengaruhi kejadian ISPA. Pekerja dengan usia $>40$ tahun memiliki risiko lebih besar untuk terkena ISPA. Semakin bertambahnya usia seseorang maka kerentanan terhadap efek paparan semakin meningkat, fungsi organ tubuh semakin menurun, imunitas tubuh melemah, kapasitas vital paru nya akan semakin menurun karena adanya kemunduran fungsi organ sehingga lebih rentan terhadap paparan polutan yang berakibat pada timbulnya gangguan pernapasa (Fitriyani, 2011). Hasil penelitian dari Irva Iriyana (2014), menunjukan terdapat pengaruh antara umur sopir bus terhadap gangguan fungsi paru. Sopir bus dengan umur 55-61 tahun berpeluang berisiko mengalami gangguan fungsi paru sebesar 11 kali dibanding umur 27-33 tahun.

Penelitian dari Nelson \& William (2007), diperoleh hasil, laki-laki berisiko menderita ISPA lebih besar dibandingkan perempuan karena kebutuhan oksigen pada laki-laki lebih banyak daripada perempuan. Sedangkan menurut Supraptini, Hananto, Hapsari (2010), menyatakan bahwa lak-laki lebih berisiko terkena ISPA sebesar 1,038 kali dibandingkan perempuan karena laki-laki lebih banyak melakukan aktivitas di luar rumah dibandingkan dengan perempuan sehingga mengakibatkan cenderung untuk mendapatkan pajanan yang lebih besar terhadap agent penyakit (WHO,2007)

Semakin lama seseorang bekerja maka semakin banyak dia terpapar oleh bahaya yang ditimbulkan dari lingkungan kerja tersebut. Hal tersebut dibuktikan oleh Noer \& Martiana (2013), pekerja yang bekerja >10 tahun lebih berisiko terkena ISPA dibandingkan dengan pekerja yang bekerja $<10$ tahun. Semakin lama petugas bekerja di suatu area kerja maka akan 
semakin sering terpajan dan semakin banyak yang terhirup dari lingkungan kerja tersebut (Suma'mur P, 2009). Petugas dengan masa kerja >10 tahun memiliki peluang 8 kali lebih besar terkena ISPA.

Menurut Suryo (2010), kebiasaan merokok dapat meningkatkan terjadinya ISPA 2,2 kali. Penelitian yang dilakukan oleh Luciana pada tahun 2010 menyatakan bahwa rokok dapat meningkatkan kelainan paru dimana iritasi yang persisten pada saluran pernafasan akibat rokok dapat menyebabkan adanya perubahan pada struktur jaringan paru-paru sehingga lebih rentan terkena ISPA. Penelitian Hendrawati, dkk tahun 1998 menyatakan bahwa kebiasaan merokok dengan gangguan fungsi pada paru-paru memiliki hubungan disebabkan karena frekuensi merokok pada durasi lama merokok, macam-macam rokok yang dihisap, banyaknya batang rokok yang dihisap setiap hari pada pekerja secara berlebihan. Penelitian yang dilakukan oleh Irva Iriyana (2014), menunjukan adanya pengaruh antara kebiasaan merokok sopir bus pada gangguan fungsi paru. Sopir bus yang memiliki kebiasaan merokok mempunyai risiko terkena gangguan fungsi paru sebesar 6 kali dibandingkan yang tidak merokok.

Penyakit paru-paru akan timbul bertahun-tahun setelah tingkat paparan yang tinggi hal ini disebabkan karena kondisi kerja tertentu . Partikel-partikel yang masuk ke dalam saluran nafas dapat menimbulkan terjadinya reaksi mekanisme pertahanan non spesifik seperti batuk, bersin, gangguan transport mukosilier dan fagositosis oleh makrofag. Otot polos disekitar jalan nafas dapat terangsang sehingga terjadi penyempitan. Keadaan ini terjadi bila kadar debu melebihi nilai ambang batas yang telah dilakukan penelitian oleh Khumaidah pada tahun 2009. Bagi pekerja sopir bus yang berada di lingkungan dengan kadar polutan tinggi dalam waktu lama akan terjadinya penumpukan polutan dengan partikel kecil di alveoli sehingga efek yang ditimbulkan pada perubahan fungsi paru. Tingkat polusi udara luar yang sangat tinggi karena jarak tempuh saat berkendara memiliki beberapa faktor risiko terhadap lama paparan di jalan raya terhadap kejadian ISPA yaitu pemakaian APD (meliputi masker dan helm standart SNI) dan kecepatan rata-rata saat berkendara menuju kampus ataupun ke rumah serta jarak tempuh. Pemakaian APD sangat berhubungan dengan kejadian ISPA karena Alat Pelindung Diri mempunyai manfaat untuk menyaring udara pernapasan kemungkinan kelainan yang terjadi di paru-paru dapat dihambat disebabkan dari penumpukan udara kotor. Memakai masker sesuai dengan standar kesehatan misalnya memakai masker dengan benar, macem-macem masker yang digunakan dapat disesuaikan pada kebutuhan dan tempat untuk beraktivitas sehingga dapat meminimalisirkan bahaya potensial yang disebabkan oleh paparan polusi udara. 
Penelitian yang dilakukan secara keseluruhan mayoritas responden lebih banyak memiliki kebiasaan yang kadang-kadang memakai APD, terkait dari karakternya pada perilaku berkendara di jalan raya, kebanyakan responden pernah melanggar rambu-rambu lalu lintas dan kurang berhati-hati dalam berkendara, yaitu tidak memakai alat pelindung diri (APD) dengan baik dan benar seperti halnya tidak menggunakan helm standart serta tidak menggunakan masker penutup hidung dan mulut. Menurut teori WHO pada tahun 2008, menjelaskan bahwa alat pelindung pernapasan digunakan untuk upaya pencegahan dan pengendalian infeksi ini adalah perlindungan terhadap mukosa mulut dan hidung, serta kebersihan tangan. Jika ada risiko cipratan pada muka, mukosa mata juga dapat dilindungi. Sedangkan laju cepatnya berkendara juga akan menyebabkan jumlah emisi yang dikeluarkan oleh suatu kendaraan. Pada kelompok kasus lebih banyak mengendarai sepeda motor dengan kecepatan lambat sedangkan kelompok kontrol dengan kategori cepat sehingga dapat disimpulkan bahwa sebagian besar kelompok kasus banyak terkena dampak emisi gas karbon monoksida (CO) yang disebabkan dari kendaraan bermotor miliknya maupun emisi gas yang disebabkan oleh pengendara lain terutama pada saat berhenti terkena macet. Semakin sering lama seseorang berada di jalanan juga semakin sering banyak zat beracun yang dihasilkan dari pembuangan dari kendaraan bermotor yang dihirup dan dapat menimbulkan masalah kesehatan. Pada Zat CO yang di hirup terus menerus dalam jumlah besar dapat menimbulkan bahaya kesehatan karena hemoglobin dalam tubuh cenderung mengikat $\mathrm{CO}$ daripada $\mathrm{O} 2$ mengakibatkan seseorang mampu kekurangan oksigen dalam tubuhnya sehingga menimbulkan efek jangka panjang bagi kesehatan seperti sesak nafas, terinfeksi kuman TBC atau mikroorganisme lain yang menyerang paru-paru dan Penyakit Paru Obstruktif Kronik (PPOK) sedangkan efek jangka pendeknya adalah batuk-batuk, mudah lelah dan mengantuk. Namun untuk waktu tempuh saat menuju kerumah atau ke kampus waktu tempuh saat berkendara diketahui berhubungan dengan lama terpaparnya polutan. Sering mengalami waktu tempuh yang jauh maka semakin sering lama seseorang terpapar oleh bahan polutan dan semakin banyak macam polutan yang terhirup masuk ke dalam saluran pernapasan. Menurut penelitian yang dilakukan oleh Hyatt et al (2006), bahwa pemaparan debu actor dapat menimbulkan terjadinya penyakit paru kronik. Keadaan tersebut terjadi setelah penderita mengalami kontak dalam waktu yang lama, hal ini terjadi lebih dari 10 tahun dan jarang terjadi di bawah 10 tahun. Dari pernyataan menunjukkan bahwa waktu tempuh berkendara yang jauh dapat terkena penyakit paru kronik.

Berdasarkan hasil penelitian yang dilakukan oleh Irva Iriyana (2014), menunjukan hasil pengaruh antara lama paparan sopir bus terhadap gangguan fungsi paru. Sopir bus yang 
terkena paparan $\geq 5$ tahun mempunyai tingkat risiko gangguan fungsi paru sebesar 5 kali dibandingkan dengan lama paparan yang $<5$ tahun.

Berdasarkan hasil penelitian yang dilakukan oleh Rezkha Mala Ludyaningrum (2017), didapatkan hasilnya bahwa ada hubungan antara perilaku berkendara yang terdiri dari pemakaian APD dan kecepatan rmayoritas berkendara dengan kejadian ISPA. Jarak waktu tempuh memiliki hubungan dengan kejadian ISPA. Bagi responden yang tidak memakai APD akan lebih berisiko mengalami ISPA 2,6 kali dibandingkan dengan responden yang selalu memakai APD. Kecepatan mayoritas berkendara $<40 \mathrm{~km} / \mathrm{jam}$ memiliki risiko terkena ISPA 5,4 kali dibandingkan responden dengan kecepatan $>40 \mathrm{~km} / \mathrm{jam}$. Pada jarrak tempuh yang $\geq$ $5 \mathrm{~km}$ memiliki risiko terkena ISPA 5,156 kali dibandingkan responden dengan jarak tempuh yang $<5 \mathrm{~km}$. bahwa perilaku berkendara dan waktu tempuh berhubungan dengan kejadian ISPA.

Status gizi merupakan faktor risiko terhadap kejadian ISPA. Berdasarkan Nuryanto (2012) menyatakan bahwa status gizi kurang maka akan berisko untuk terjadinya ISPA, balita dikatakan ststus gizinya baik jika di nilai perbandingan antara BB dan Umur adalah dengan SD 2 dan apabila nilai SD kurang 2 maka dikatakan status gizi kurang. Sedangkan menurut penelitian yang dilakukan oleh Almatser pada tahun 2003, timbulnya gizi tidak hanya disebabkan dari asupan makanan yang kurang, tetapi juga penyakit. Anak yang mendaptkan cukup makanan tetapi sering menderita sakit, pada akhirnya dapat mengalami gizi kurang. Demikian juga pada anak yang tidak mendapatkan makanan yang cukup, sehingga daya tahan tubuhnya melemah dan mudah terkena penyakit ISPA.

Status gizi merupakan faktor yang mempengaruhi tingginya kejadian ISPA. ISPA pada anak dibawah dua tahun harus diwaspadai oleh orang tua, karena dapat menyebabkan kematian menurut penelitian Yulia tahun 2010. Pada balita dengan gizi yang kurang akan mudah terkena ISPA dibandingkan dengan balita yang memiliki gizi normal disebabkan oleh faktor daya tahan tubuh yang kurang. Penyakit infeksi sendiri juga akan menyebabkan balita tidak nafsu makan dan terjadinya kekurangan gizi. Pada keadaan gizi yang kurang, balita lebih mudah terkena "ISPA berat" maka serangannya lebih lama. Sedangkan menurut Kartasasmita (2005), menjelaskan bahwa prevalensi ISPA cendrung lebih tinggi pada anak dengan status gizi yang buruk. Status gizi merupakan faktor risiko yang paling berpengaruh dalam kejadian ISPA pada balita. Risiko yang lebih tinggi terhadap ISPA sangat mempengaruhi terjadinya gangguan status gizi pada balita, semakin parah risiko terkena ISPA yang dialami sama balita 
akan mengakibatkan status gizi yang buruk pada balita dan sebaliknya balita yang mengalami gizi buruk maka ISPA yang dialami akan semakin parah.

\section{SIMPULAN DAN REKOMENDASI}

Gejala sakit mengarah ke ISPA pada Pegawai LLAJ Jakarta Timur, sebesar 5,22\% mengalami pilek/hidung tersumbat/berair, batuk-batuk saat bekerja hanya 2,24\% dan yang mengalami tenggorokan terasa sakit sebanyak 1,49\%. Dinas perhubungan Jakarta Timur sebelumnya tidak mempunyai data terkait kesehatan pegawai. Analisis pengaruh penggunaan Alat Pelindung Diri (APD) terhadap terjadinya gejala Infeksi Saluran Pernafasan Akut (ISPA) tidak dapat kami lakukan karena jumlah kasus yang kecil dan semua responden menggunakan APD (Masker Kain, Masker Bedah, Masker N95, Masker lainnya) hal ini terjadi karena penelitian ini dilakukan pada saat kondisi Pandemic Covid 19 dan adanya pemberlakuan wajib $3 \mathrm{M}$ (memakai masker, mencuci tangan dan menjaga jarak) selain itu karena adanya keterbatsan ruang gerak atau Pembatasan Sosial Berskala Besar (PSBB) mengakibatkan paparan udara atau emisi udara dari mobilisasi kendaraan bermotor sangat rendah.

Saran untuk mengurangi risiko ISPA pada Pegawai LLAJ adalah Dinas Perhubungan bekerjasama dengan Dinas Kesehatan untuk melakukan pengecekan kesehatan seluruh pegawai LLAJ baik pada saat awal pegawai masuk kerja atau secara berkala agar terekam jejak medis pegawai yang mengalami penyakit akibat pekerjaan terutama ISPA, hearing loss (kehilangan pendengan), hipertensi, iritasi kulit, dan penyakit akibat terpaparnya udara, Pentingnya terjadi rotasi pekerjaan seperti rotasi wilayah kerja dari area yang tinggi paparan polutannya ke wilayah/area yang rendah karena polutan setiap wilayah berbeda-beda. Khusus masker, hendaknya setiap hari harus mengalami pergantian (minimal 2 kali per hari per orang pegawai), masker yang baik minimal jenis masker N95, dikarenakan masker ini mampu

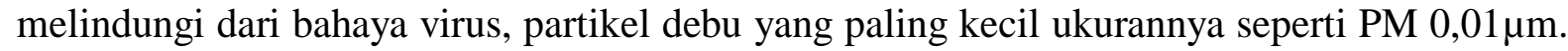
Budayakan olahraga dikalangan pekerja, untuk mempertahankan tubuh tetap fit/bugar, dan menyarakan agar makan makanan yang bergizi. 


\section{REFERENSI}

1. Kementrian Kesehatan RI. 2013. Riset Kesehatan Dasar pada tahun 2013.

2. Noer, R. H, \& Martiana, T. 2013. Hubungan karakteristik dan perilaku pekerja dengan gejala ISPA di Pabrik asam fosfat dept. produksi III. PT. Petrokimia Gresik. The Indonesian journal of occupational safety and health Vol.2 No.2, 130-136.

3. Fitriyani. 2011. Pajanan PM10 terhadap kejadian gejala ispa pada pekerja pergudangan semen di Kota Madya Palembang. Tesis Universitas Indonesia Program Studi Ilmu Kesehatan Masyarakat.

4. Nelson, K.E., \& William, C. F. 2007. Infectious disease epidemiology : Theory and practice. Boston : Jones Adn Bartlett.

5. Supraptini, Hananto, M., \& Hapsari, D. 2010. Faktor-faktor pencemaran udara dalam rumah yang berhubungan dengan kejadian ispa pada balita di Indonesia. Jurnal Ekologi Kesehatan.9 (2), 1238-1247.

6. World Organization. 2007. Pencegahan dan pengendalian infeksi saluran pernapasan akut (ISPA) yang cenderung menjadi epidemi dan pandemi di fasilitas pelayanan kesehatan.

7. Noer, R. H, \& Martiana, T. 2013. Hubungan karakteristik dan perilaku pekerja dengan gejala ISPA di Pabrik asam fosfat dept. produksi III. PT. Petrokimia Gresik. The Indonesian journal of occupational safety and health Vol.2 No.2, 130-136.

8. Yusnabeti, Wulandari, R.A ., \& Luciana, R. 2010. PM10 dan infeksi saluran pernafasan akut pada pekerja industry mebel. Makara Kesehatan vol 14, No.1, 25-30.

9. Suma'mur. 2009. Higene Perusahaan dan Kesehatan Kerja. Jakarta: Sagung Seto.

10. Suryo, J. 2010. Herbal Penyembuhan Gangguan Sistem Pernafasan. Yogyakarta : Bentang Pustaka.

11. Hendrawati WL, Pruhartono J, danYunus F. 1998. Pengaruh Debu Kayu Terhadap Paru Dan Faktor-Faktor Risikonya Di Kalangan Pekerja Industri Permebelan Kayu di Bogor. Journal Respiratory Indonesia. Vol 18 No: 04. 137-145.

12. Khumaidah. 2009. Analisis Faktor-Faktor yang Berhubungan Dengan Gangguan Fungsi Paru pada Pekerja Mebel PT Kota Jati Furnindo Desa Suwawal Kecamatan Mlonggo Kabupaten Jepara. Tesis. Semarang: UNDIP. 
13. Hyatt, R.E., Scalon, P.D. and Nakamura, M. 2006. Static (Absolute) Lung Volume, in Interpretation of Pulmonary Function Tes-A Practical Guide, 2 nd edition, Philadelphia: Lippicolt William \& Wilkins.

14. WHO, 2008. Pencegahan dan Pengendalian Infeksi Saluran Pernapasan Akut (ISPA) yang Cenderung Menjadi Epidemi dan Pandemi di Fasilitas Pelayanan Kesehatan, Jenewa: World Health Organization.

15. Yulia, 2010. Faktor-faktor yang Mempengaruhi Kejadian ISPA. Available at: http://www.depkesri.com. [Accessed August 15, 2014]

16. Anwar, 2009. Pentingnya Gizi bagi Manusia. Available at: www.digilib. unila.ac.id/178/3/ [Accessed August 15, 2014]. 